\title{
The nature and origin of climatic fluctuations in Northeastern North America
}

\author{
La nature et l'origine des fluctuations climatiques dans le \\ nord-est de l'Amérique du Nord \\ Die Natur und Herkunft klimatischer Veränderungen im \\ nord-östlichen Nordamerika
}

\author{
R. G. Barry
}

Volume 35, numéro 1, 1981

Quatrième Colloque sur le Quaternaire du Québec

URI : https://id.erudit.org/iderudit/1000376ar

DOI : https://doi.org/10.7202/1000376ar

Aller au sommaire du numéro

Éditeur(s)

Les Presses de l’Université de Montréal

ISSN

0705-7199 (imprimé)

1492-143X (numérique)

Découvrir la revue

Citer cet article

Barry, R. G. (1981). The nature and origin of climatic fluctuations in

Northeastern North America. Géographie physique et Quaternaire, 35(1), 41-47.

https://doi.org/10.7202/1000376ar

\section{Résumé de l'article}

Nous examinons ici les éléments de la circulation atmosphérique et du climat dans le nord-est du Canada. Nous nous attardons surtout au rôle et à la variabilité du creux barométrique supérieur. Nous voyons que les déplacements longitudinaux du creux barométrique estival moyen engendrent des anomalies tant au niveau des températures de l'air qu'à celui des conditions de la glace marine dans la région de l'île de Baffin. Nous résumons également les types d'anomalies climatiques affectant le Labrador-Ungava et le Keewatin, et associés aux déplacements du creux barométrique. Nous examinons deux cas où des données de ce genre ont été appliquées à des problèmes d'ordre paléoclimatique. Le premier porte sur la présence de pollen issu d'essences exotiques à l'île de Baffin et sur ses relations, considérées possibles, avec les courants atmosphériques venant du sud. Nous concluons qu'il n'est pas encore possible de se fonder sur l'abondance de pollen pour évaluer avec certitude les paléo-vents. Par ailleurs, à la lumière des données climatiques disponibles, nous nous sommes brièvement penchés sur l'amorce des glaciations et l'extension de la calotte glaciaire au cours du dernier maximum glaciaire. Enfin, nous étudions le rôle des variations de l'orbite terrestre, qui affectent selon les saisons le rayonnement solaire, en nous référant à la dernière période glaciaire.
Tous droits réservés @ Les Presses de l’Université de Montréal, 1981
Ce document est protégé par la loi sur le droit d'auteur. L’utilisation des services d'Érudit (y compris la reproduction) est assujettie à sa politique d'utilisation que vous pouvez consulter en ligne.

https://apropos.erudit.org/fr/usagers/politique-dutilisation/ 


\section{THE NATURE AND ORIGIN OF CLIMATIC FLUCTUATIONS IN NORTHEASTERN NORTH AMERICA}

R.G. BARRY, Cooperative Institute for Research in Environmental Sciences and Department of Geography, University of Colorado, Boulder, Colorado 80309, U.S.A.

ABSTRACT Features of the atmospheric circulation and climate of northeastern Canada are reviewed. In particular, the role of the upper level trough and its variability are discussed. It is shown that longitudinal displacements of the mean summer trough create anomalies of both air temperature and sea ice conditions in the region of Baffin Island. Climatic anomaly patterns in LabradorUngava and Keewatin associated with trough displacements are also summarized. Two examples of the application of such information to paleoclimatological questions are discussed. One concerns the influx of "exotic" tree pollen into Baffin Island and its previously postulated relationship to southerly airflow. It is concluded that pollen peaks cannot yet be reliably used as a paleowind index. The pattern of glacial inception and ice sheet extension during the Last Glacial Maximum is also briefly considered in the light of the available climatic information. Finally, the role of orbital variations affecting the seasonal pattern of solar radiation is discussed with reference to the last glacial cycle.
RÉSUME La nature et l'origine des fluctuations climatiques dans le nordest de l'Amérique du Nord. Nous examinons ici les éléments de la circulation atmosphérique et du climat dans le nord-est du Canada. Nous nous attardons surtout au rôle et à la variabilité du creux barométrique supérieur. Nous voyons que les déplacements longitudinaux du creux barométrique estival moyen engendrent des anomalies tant au niveau des températures de l'air qu'à celui des conditions de la glace marine dans la région de l'île de Baffin. Nous résumons également les types d'anomalies climatiques affectant le Labrador-Ungava et le Keewatin, et associés aux déplacements du creux barométrique. Nous examinons deux cas où des données de ce genre ont été appliquées à des problèmes d'ordre paléoclimatique. Le premier porte sur la présence de pollen issu d'essences exotiques à l'île de Baffin et sur ses relations, considérées possibles, avec les courants atmosphériques venant du sud. Nous concluons qu'il n'est pas encore possible de se fonder sur l'abondance de pollen pour évaluer avec certitude les paléo-vents. Par ailleurs, à la lumière des données climatiques disponibles, nous nous sommes brièvement penchés sur l'amorce des glaciations et l'extension de la calotte glaciaire au cours du dernier maximum glaciaire. Enfin, nous étudions le rôle des variations de l'orbite terrestre, qui affectent selon les saisons le rayonnement solaire, en nous référant à la dernière période glaciaire.
ZUSAMMENFASSUNG Die Natur und Herkunft klimatischer Veränderungen im nord-östlichen Nordamerika. Die Karakterzüge der atmosphärischen Zirkulation und das Klima nord-ost Kanadas werden uberprüft. Besonders diskutiert wird die Rolle der Tiefdrucklagen in der Oberschicht und seine Variationen. Es wird gezeigt, dass longitudinale Verschiebungen des Durchschnitts Sommertiefs Anomalien sowohl in Lufttemperaturen als auch in See-Eis Verhältnissen in der Baffin Insel Gegend hervorrufen. Klimatische Anomalien in Labrador Ungava und Keewatin in Verbindung mit Tiefdruck verschiebungen sind auch erwähnt. Zwei Beispiele der Anwendung dieser Information auf paläoklimatische Fragen werden gezeigt. Eines behandelt die Einwanderung von "exotischen" Baumpollen in die Baffin Insel und seine früher angenommene Beziehung zu südlichen Luftströmungen. Es wird beschlossen, dass Spitzen in der Pollenkurve noch keinen zuverlässigen Paläowindindex ergeben. Die Modelle von Glazialinzeption und Eisdeckenausdehnung während des letzten GlazialMaximums sind auch kurz behandelt im Lichte von worhandenen klimatischen Erkenntnissen. Schliesslich, die orbitalen Veränderungen, welche der jahreszeitlichen Wechsel der Sonnenbestrahlung beeinflussen, werden im Zusammenhang mit dem letzten Eiszeit Zyklus diskutiert. 


\section{INTRODUCTION}

The Arctic and Subarctic zones of eastern Canada are of considerable interest from the standpoint of research into climatic changes and their environmental effects. The area, in view of its recognized sensitivity to climatic fluctuations, is a key one for understanding the history of the last glacial cycle in North America. Based on continuing field studies, our picture of the growth and disappearance of the Laurentide ice sheet and of subsequent vegetational recolonization of subarctic Canada is undergoing a rapid transformation. This paper aims to provide a climatological background to the question and controversies arising from these studies. In particular, an attempt is made to delimit the primary controls of climatic conditions in the area and to outline the range and sources of variability likely to have occurred during late- and postglacial time.

\section{CLIMATOLOGICAL FEATURES OF THE CIRCULATION}

The atmospheric circulation over eastern Canada is dominated by a mean tropospheric trough, located about $70^{\circ}-75^{\circ} \mathrm{W}$ in both winter and summer. This feature of the hemispheric long-wave structure is primarily caused by differential land-sea heating effects on the lower troposphere reinforced, mainly in winter, by large-scale orographic influences on the flow at upper levels downstream of the mountain ranges of western North America (KASAHARA and WASHINGTON, 1971). Despite the seasonal reversal of the land-sea thermal gradient, a weaker upper trough and a surface low are present over the area in summer (SMAGORINSKY, 1953, Fig. 7). The mean trough is important climatically since it reflects the general steering of surface cyclones, roughly parallel to the mean $500 \mathrm{mb}$ contours. Also, throughout the year, although less frequently in summer, lower level cyclonic vorticity is enhanced on the eastern limb of an upper trough (by high-level divergence) and hence cyclones tend to regenerate or intensify over the Labrador Sea. From here, a frequent track enters Davis Strait-Baffin Bay where many systems slowly decay. A mean frontal zone crosses the central part of the Labrador-Ungava Peninsula in summer, although its exact provenance is unresolved (BRYSON, 1966; BARRY, 1967; HARE, 1968). Poleward of this front, arctic air predominates and this boundary (in summer) seems to be closely related to the present forest-tundra ecotone in both North America and Eurasia (BRYSON, 1966; KREBS and BARRY, 1970). In the adjacent seas, ice persists into the summer due to ice advection in the Labrador Current and to the combined role of low water and air temperatures and high cloudiness. The climatic factors are themselves partly attributable to the presence of the ice.

We can now examine the major components of interannual variability and short-term climatic fluctuations in terms of these basic atmospheric and oceanic characteristics.

\section{CIRCULATION VARIABILITY}

The mean trough varies in location and amplitude in relation to changes in the external thermodynamic forcing and because it represents the aggregate effect of individual short-wave perturbations. KEEN (1980) shows that displacements of the mean $700 \mathrm{mb}$ trough in summer occur in association with changes in the strength of the hemispheric westerlies and concomitant adjustments in the wavelength of the mean wave structure. The significance of these circulation changes can be illustrated from Keen's analysis of summers 1946-76. Summer temperatures around Baffin Bay show a marked decrease between the early and later parts of the record (cf. BRADLEY, 1973) and there is an associated increase in severity of sea ice conditions (Fig. 1) (KEEN, 1977). These changes are associated with an observed eastward displacement of the $700 \mathrm{mb}$ trough over eastern Canada, which gives rise to an enhanced northwesterly flow component in the troposphere over Baffin Island. Analysis of sea ice conditions for the Davis Strait area suggests that this atmospheric pattern also favors late (summer) ice retreat and early (fall) ice advance (CRANE, 1978; DEY, 1980). The trough displacements are attributed by KEEN (1980) to circulation readjustments induced by tropospheric cooling in high latitudes which accentuates the north-south thermal gradient ${ }^{1}$ and thereby strengthens the westerlies. In turn, this increases the wavelength downstream of the more "anchored' Alaska-Yukon ridge. While the details are complex, the general argument seems eminently reasonable ${ }^{2}$. The degree of statistical "explanation" provided by Keen's analysis for summers 1946-76, using a 1-2-1 smothing (giving an effective 2-year average to suppress interannual variability), is as follows: at $70^{\circ} \mathrm{N}$, the hemispheric and regional air temperatures have a correlation of +0.55 ; the date of clearance of sea-ice from Baffin Bay correlates strongly with regional summer temperatures $(r=+0.74)$ and also with hemispheric temperature $(+0.56)$.

1. By contrast, it is worth noting that meridional gradients of sea surface temperature in the North Atlantic weakened due to small changes off southern Greenland and a large drop in the western ocean $\left(35^{\circ}-45^{\circ} \mathrm{N}, 40^{\circ}-50^{\circ} \mathrm{W}\right)$ in the mid1950s (PERRY, 1974).

2. Keen's analysis also indicates that frequency changes of daily circulation types for the region fail to account for the temperature changes. 


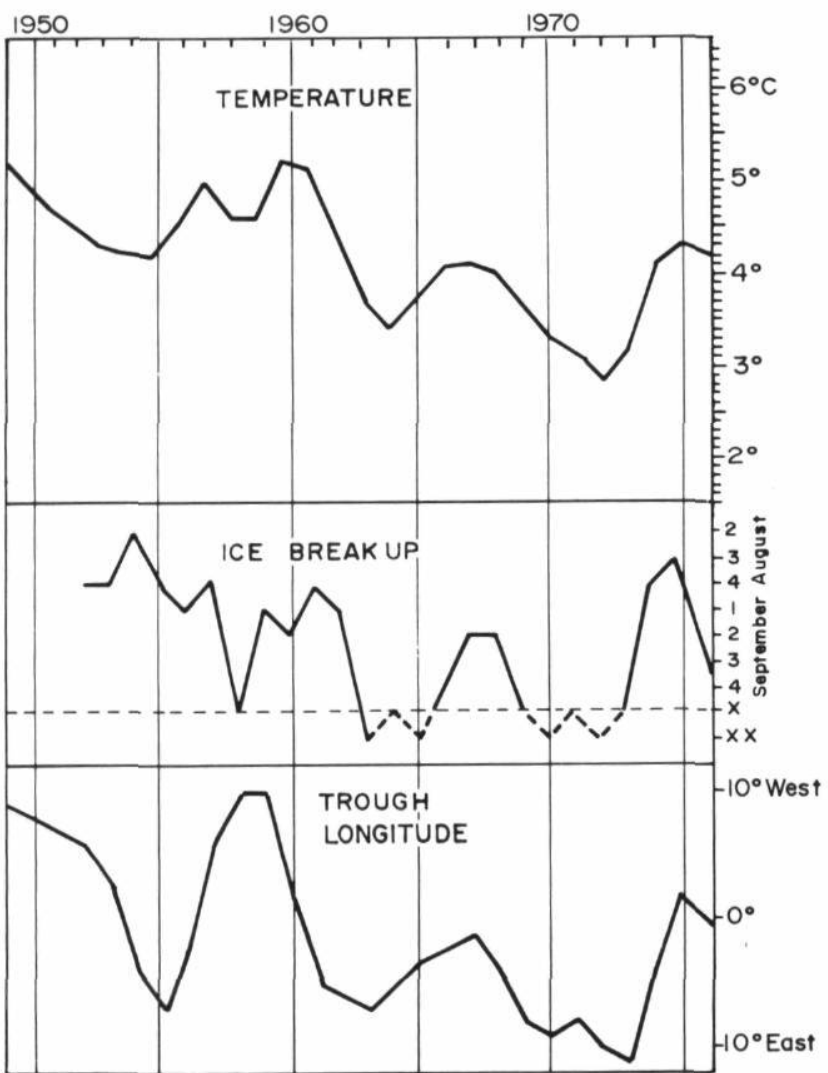

FIGURE 1. Association between summer climate, sea ice conditions and atmospheric circulation in the eastern Canadian Arctic, 1949-76 (after KEEN, 1980). Top: mean summer temperature around Baffin Bay (average of Clyde, Upernavik and Egedesminde); yearly values are smoothed by a 1-2-1 running mean. Middle: week of total clearance of ice from Baffin Bay (1952-76); symbols on scale denote persistence of small (x) and appreciable (xx) amounts of ice. Bottom : longitude of the $700 \mathrm{mb}$ trough over eastern Canada expressed as deviations from the long-term average (ca. $72^{\circ} \mathrm{W}$ ), smoothed by a 1-2-1 running mean.

Relations entre le climat estival, les conditions de la glace marine et la circulation atmosphérique dans l'est de l'Arctique canadien, de 1949 à 1976 (d'après KEEN, 1980). En haut: température estivale moyenne autour de la mer de Baffin (moyennes de Clyde, Upernavik et Egedesminde); les résultats annuels sont uniformisés selon une moyenne mobile de 1-2-1. Au centre: semaine au cours de laquelle la mer de Baffin est totalement libre de glace (1952-1976); le long de l'échelle verticale les symboles $x$ et $x x$ indiquent respectivement la présence de glace faible et appréciable. En bas: au-dessus de l'est du Canada, longitude du creux barométrique s'écartant de la moyenne à long terme (ca $72^{\circ}$ ) uniformisée selon la moyenne mobile de 1-2-1.

The summer cooling, associated with an eastwarddisplaced trough in the case of Baffin Island, is not apparent further south. In the subarctic, cool summer months are more apparent in Labrador-Ungava and Keewatin when the trough is deeper than normal over Hudson Bay (BRINKMANN and BARRY, 1972). Such months are also wetter than average over Labrador-
Ungava and drier west of the Bay. When the trough is displaced eastward, Keewatin and the Hudson Bay area tend to be drier than average with heavy precipitation over Labrador.

For winter months, snowy "mild" conditions affect both Keewatin and Labrador-Ungava when the $700 \mathrm{mb}$ trough is weaker than normal and displaced westward, with anomalous southeasterly flow components advecting heat and moisture from the western North Atlantic (cf. BARRY, 1966). It should also be noted that recent work (Barry and Carleton, unpub.) indicates that, while snowy months tend to have positive temperature anomalies, there is no significant correlation between temperatures and snowfall amount.

\section{SIGNIFICANCE OF CIRCULATION VARIABILITY}

The work of KEEN (1980), described above, supports the earlier results of VAN LOON and WILLIAMS (1976a, b) which show that short-term climatic anomalies (over a few decades) are linked closely to anomalies in the modes of atmospheric circulation.

The tendency for circulation modes is a welldocumented feature of at least the winter season in the northern hemisphere. VAN LOON and ROGERS (1978); ROGERS and VAN LOON, 1979; ROGERS, 1979), for example, have described a North Atlantic pressure oscillation (the Greenland-northern Europe winter temperature "see-saw") and an analogous North Pacific oscillation. Each oscillation represents a major independent element of hemispheric circulation and both contribute to regional climatic anomalies, including temperature and sea ice conditions. The North Atlantic Oscillation, in particular, displays teleconnections over a large part of the hemisphere.

DIAZ and QUAYLE (1980) similarly find a dominant east-west mode of variation in large-scale annual anomalies over the United States for three subperiods within the records for 1895-1977. VAN LOON and WILLIAMS (1976b) note that a circulation connection is generally less obvious in summer, due to weaker temperature gradients and a lesser wave amplitude, but the associations they find over North America-Greenland for 1942-72 are in line with Keen's results (ibid, p. 125-30). However, they also argue that, since trends in the relative frequency of cyclonic activity over areas occupied by stable air masses (high latitudes and polar continents in winter, ocean surfaces in summer) may be sufficient to account for the observed temperature trends, it is unlikely that such intervals of cyclonic activity would continue in the same sense for more than, say, one hundred years. If this is so, then these short-term events may be of limited use as an analog to past climatic changes of longer duration. Despite this caveat, we have no other basis 
for analyzing past climatic regimes at the present time since climate experiments with general circulation models are limited to sensitivity analyses assuming equilibrium conditions.

\section{APPLICATIONS TO PALEOCLIMATIC PROBLEMS}

Two examples of the application of such climatic studies to paleoclimatic problems can now be discussed, one for Holocene events and the other for glaciation.

\section{1) HOLOCENE PALAEOWIND CONDITIONS}

The trough displacement analysis of KEEN (1980), discussed above, has implications for the interpretation of exotic peaks in Holocene records from peat sections in Baffin Island. NICHOLS et al. (1978) ascribe such peaks to intervals of increased southerly airflow over eastern Canada transporting the pollen of Pinus, Picea and Alnus crispa between 800 and 1900 km beyond the northernmost limits of the living species. An analysis of present-day synoptic meteorological flow patterns over eastern Canada (BARRY et al., 1981) indicates that air flow from some part of the boreal forest reaches Baffin Island on an average of 11 days during the May-June period of significant atmospheric pollen loading in the source regions. The modern deposition rate of the three exotic species has a mean value of about 2 grains $\mathrm{cm}^{-2} \mathrm{yr}^{-1}$ in eastern Baffin Island (NICHOLS, 1977; ANDREWS et al., 1979). Assuming a concentration of 20 grains $\mathrm{m}^{-3}$ in a $1 \mathrm{~km}$-deep plume, a deposition rate of 2 grains $\mathrm{cm}^{-2}$ per event would be expected if all of the exotic pollen were washed out, or settled out, over the area. These figures imply a dilution factor of about ten. Hence, to account for the observed pollen peaks of 25-60 grains $\mathrm{cm}^{-2} \mathrm{yr}^{-1}$ (ANDREWS et al., 1979), an increase in frequency of southerly incursions to > 135 days would be required, which is clearly not possible. The exotic peaks in the Holocene record also show an unusually high ratio of Alnus: Pinus, suggesting a primary source in northeastern Labrador-Ungava. Only two synoptic events per season at present give trajectories that can transport pollen northward from Labrador-Ungava, and therefore, if it is considered that Labrador-Ungava is the only contributor at present to the mean value of 2 grains $\mathrm{cm}^{-2} \mathrm{yr}^{-1}$, an increase of $12-30$ fold in southerly airflow is needed, to account for the pollen peaks. The estimated flow events (i.e. 24-60 days of southerly flow) still seems too large to accommodate within the allotted 8-week interval (May - June). Consequently, the possibility of large variations in pollen productivity or of variations in sedimentation rate need to be considered. DAVIS (1980) analyzing lake sediments, for example, discounts the supposed periodicities in the pollen peak record identified by ANDREWS et al. (1979) from peat sections.

Another problem is that while Keen's results demonstrate that warmer (cooler) summers during the 1950s (1960s) occurred with a $700 \mathrm{mb}$ trough displacement to the west (east), respectively, the trajectory study shows no change in the frequency of southerly trajectories from Labrador-Ungava between these two periods. Warmer summers can evidently occur without more frequent southerly airflow, although the reverse may not hold true.

The conclusion from this analysis must be that exotic pollen peaks cannot yet be interpreted as a reliable indicator of paleowind frequency. All than can safely be said is that peaks suggest augmented air circulation between the boreal forest and the Low Arctic, perhaps combined with changes in pollen productivity.

\section{2) GLACIAL INCEPTION}

The synoptic approach to assessing conditions that might favor ice growth in eastern North America has been discussed previously (BARRY, 1960; 1966; 1973) and need not be restated. Those early suggestions concerning the role of easterly airflow occurring with winter cyclones tracking towards Baffin Island or southern Greenland, and of the moisture flux and winter snowfall associated with such events, have been corroborated and expanded by the more recent work of JOHNSON and McCLURE (1976) and RUDDIMAN and McINTYRE (1979). Their results, and those of FILLON (1980) confirm the necessity for a warm northwestern Atlantic-Labrador Sea to serve as a moisture source for ice sheet growth. However, it should be emphasized that it is the cyclonic activity which causes heavy precipitation in southeastern Baffin Island at present, not the effect of local open water in Davis Strait, as argued by HAWKINS (1980) with reference to late Foxe (last glaciation) glacier advances. While such results can be used to argue a case for the general significance of northeastern Canada for ice sheet inception and for the synoptic patterns likely to have involved, they seem unlikely to be able to help resolve the problem of a single dome or multi-dome model for the Laurentide ice sheet (cf. SUGDEN, 1977; SHILTS, 1980). All that can be said is that the accumulation of elongated domes of the kind depicted by Shilts would seem more probable if the modern climatic patterns of snowfall and snow cover distribution suggested similar localized gradients. From the map of snowfall in WILSON (1971, Fig. 20) and of April 30 snow cover in POTTER (1965) there is no clear indication that a proto-dome form might develop in Keewatin, although central Labrador-Ungava is more favorable. 
Topography is also apparently not involved in the former instance.

The temporal sequence of glacial advances identified by TELLER and FENTON (1980) in southeastern Manitoba indicates Laurentide ice from the northeast affecting the area about $24,000-22,000 \mathrm{BP}$ then, following a slight retreat, Keewatin ice advance between about 20,000 and 13,500 BP. This sequence of ice build-up is the opposite of that expected from general climatological considerations since an ice sheet over the eastern area should anchor a deep trough causing anticyclonic vorticity in the upper level north-westerly flow over Keewatin and, therefore, less precipitation (BRINKMANN and BARRY, 1972). Nevertheless, WILLIAMS (1978) showed that anomalous snow cover northwest of Hudson Bay in October causes increased precipitation over most of northern Canada. WILLIAMS (1979) also found Keewatin to be rather more susceptible to initial glacierization than Labrador-Ungava. Consequently, his results are not in conflict with present glacial-geomorphological interpretations, although the possible climatic controls of the changing patterns and dominance of the different Laurentide ice sheet domes cannot yet be assessed.

\section{POSSIBLE CAUSAL FACTORS}

The key climate-forcing factors to be considered with reference to late- and postglacial events are the varying levels of seasonal solar radiation, related to the earth's orbital elements, and the secondary regional effects of the ice masses and surface temperature gradients on the circulation regime. Insolation characteristics related to the orbital elements have been reexamined recently by BERGER (1978a). By analyzing the annual cycle of insolation anomalies at $60^{\circ} \mathrm{N}$, he shows that a recurrent pattern with a strong summer maximum is replaced within 7,000 years by a deep minimum. This pattern is calculated to have begun within the last interglacial-glacial cycle around 127, 105, 84 and 13 thousand BP. Compared to mean values for the last million years, a positive anomaly of $100 \mathrm{cal} \mathrm{cm}^{-2} \mathrm{dy}^{-1}\left(48.5 \mathrm{~W} \mathrm{~m}^{-2}\right)$ occurs in the summer months at $129,000 \mathrm{BP}$, contrasting with a negative anomaly of $86 \mathrm{cal} \mathrm{cm}^{-2} \mathrm{dy}^{-1}\left(42 \mathrm{~W} \mathrm{~m}^{-2}\right)$ in June 118,000 BP. Other negative deviations are $72 \mathrm{cal} \mathrm{cm}^{-2} \mathrm{dy}^{-1}$ in June $73,000 \mathrm{BP}$, and $55 \mathrm{cal} \mathrm{cm}^{-2} \mathrm{dy}^{-1}$ in June-July 25,000 BP. For comparison, the mean daily insolation at $60^{\circ} \mathrm{N}$ in mid-July is $898 \mathrm{cal} \mathrm{cm}^{-2} \mathrm{dy}^{-1}$ indicating departures of $\pm 6-11$ percent. These deviations are in line with the major phases identified for the Laurentide ice sheet (see ANDREWS and BARRY, 1978). Large deviations were absent during the period 65,000 to $32,000 \mathrm{BP}$ and this pattern indicates that recent suggestions (e.g. ANDREWS et al., in press) of rapid and repetitive changes in ice volume during the last glacial cycle cannot readily be accommodated within our present understanding of the solar climate framework. Lesser fluctuations in insolation are certainly noted, however, around the time of postulated interstadials (BERGER, 1978a).

Latitudinal effects must also be considered. At 25,000 BP, BERGER (1978, Fig. 4a) shows a steep latitudinal gradient in the insolation anomalies. For the caloric northern summer ${ }^{3}$ this amounts to 4 percent less than now at $80^{\circ} \mathrm{N}$, but about 1 percent more than now at $10^{\circ} \mathrm{N}$. This difference should imply an augmented poleward heat transport, perhaps by atmospheric latent heat transport combined with an enhanced North Atlantic Drift (JOHNSON, 1980). Both factors would favour more precipitation over northeastern Canada.

The late-glacial summer insolation maximum, peaking in early summer at 11,000 BP and its subsequent minimum, with a modern deviation from the longterm mean of $-30 \mathrm{cal} \mathrm{cm}^{-2} \mathrm{dy}^{-1}$ in June, are interesting in terms of the evident lag effects in the deglaciation of North America, compared with Fennoscandinavia, and the subsequent "Hypsithermal" maximum around 5000 BP. A more complex control of the latter event is apparent.

Possible secondary effects of the ice sheets and land or sea surface temperature gradients on the atmosphere are not easily elucidated. While ice sheets are undoubtedly a major barrier to airflow and moisture transport, their specific effects on the tropospheric circulation patterns and frontal zones are not clear cut. In the Southern Hemisphere today, neither the principal zone of sea-surface temperature gradient, nor the ice edge, are coincident with the observed frontal zones (BARRY, 1980). Also, while experiments with general circulation models show that extended snow or ice covers modify the circulation, the results do not help us to understand the source of the initial growth of the ice masses, nor their eventual decay. A recent numerical experiment with a three-dimensional ice sheet model, forced by solar radiation with timedependent orbital effects included (BUDD and SMITH, 1981), shows that isostatic bedrock depression and decreasing precipitation over the central parts of the Laurentide ice sheet are essential components of the eventual decay of the ice masses. Draw-down by marine ice-streams must be another key element. (DENTON and HUGHES, 1981). Hence, deglaciation is not solely a climatic phenomenon.

3. Caloric half years are defined to be of equal length, thereby maximizing the secular variation of solar radiation due to orbital changes. 


\section{DISCUSSION}

The major climatic controls for northeastern Canada have been outlined, together with sources of short-term climatic variability. It has been shown that modern climatological analyses can be used to infer broad limits to paleoclimatic interpretations of proxy evidence. As has been illustrated, however, the results of synoptic-climatological studies can seldom be a decisive guide to regional conditions at specific times in the past. In part, this is due to the inherent variability of regional-scale circulation characteristics and in part due to the likely differences in external boundary conditions (i.e., solar radiation level, ice extent, seasurface temperature patterns, etc.). A major problem not yet adequately examined is whether certain types of circulation mode can persist for the long intervals of time seemingly necessary to grow major continental ice sheets or cause their decay. Possible changes in the location and intensity of the upper trough and associated circulation modes over eastern Canada during the Holocene are also essentially unknown. Inferred long-term temperature trends (ANDREWS et al., 1980) may imply either expansion and contraction of the entire polar vortex and shifts of the arctic front, or analogous fluctuations of the wave trough combined with longitudinal trough displacements.

Assuming the probable causal role of the orbital parameters in the major glacial-interglacial cycles, detailed seasonal processes resulting from the varying heating rates clearly must be taken into account. This will need to be done in a general global context as well as simulated regionally. However, the forcing of shorter term fluctuations (or perhaps their inherently stochastic nature) cannot yet be interpreted with any degree of confidence. For the time being, the careful documentation of the paleoclimatic record on time scales of a few thousand years is preferable to premature interpretations.

\section{ACKNOWLEDGMENTS}

The work on which this paper was based has been supported in part by the National Science Foundation, Division of Polar Programs, grant GV-28218 (to the author), and also under Climate Dynamics Program, grant ATM-77-17549 (to H. Nichols, J.T. Andrews, R.G. Barry, and J.D. Ives).

\section{REFERENCES}

ANDREWS, J.T. and BARRY, R.G. (1978): Glacial inception and disintegration during the last glaciation, Ann. Rev. Earth Planet. Sci., Vol. 6, p. 205-228.

ANDREWS, J.T., MODE, W.N. and DAVIS, P.T. (1980) : Holocene climate based on pollen transfer functions, Eastern Canadian Arctic, Arct. Alp. Res., Vol. 12, p. 41-64.
ANDREWS, J.T., WEBBER, P.J. and NICHOLS, H. (1979): A Late Holocene pollen diagram from Pangnirtung Pass, Baffin Island, N.W.T., Canada, Rev. Palaeobot. Palynol., Vol. 27, p. 1-28.

ANDREWS, J.T., SHILTS, W.W. and MILLER, G.H. (in press): Litho- and aminostratigraphic evidence for successive marine invasions of southern Hudson Bay during the Wisconsin glaciation.

BARRY, R.G. (1960): The application of synoptic studies in paleoclimatology: a case-study for Labrador-Ungava, Geog. Ann., Vol. 42, p. 36-44.

(1966): Meteorological aspects of the glacial history of Labrador-Ungava with special reference to atmospheric vapour transport, Geog. Bull. Vol. 8, p. 319-340.

(1967): Seasonal location of the Arctic front over North America, Geog. Bull., Vol. 9, p. 79-95.

(1973): Conditions favoring glacierization and deglacierization in North America from a climatological viewpoint, Arct. Alp. Res., Vol. 5, p. 171-184.

(1980): Meteorology and climatology of the seasonal sea ice zone, Cold Reg. Sci. Technol., Vol. 2, p. 133-50.

BARRY, R.G., ELLIOT, D.L. and CRANE, R.G. (1981): The palaeoclimatic interpretation of exotic pollen peaks in Holocene records from the eastern Canadian Arctic, Rev. Palaeobot. Palynol., Vol. 33 (in press)

BERGER, A. (1978a): Insolation signatures of Quaternary climatic change, in: Evolution of Planetary Atmospheres and Climatology of the Earth, Toulouse, Centre national d'études spatiales, p. 233-247.

(1978b): Long-term variations of caloric insolation resulting from the earth's orbital elements, Quat. Res., Vol. 9, p. 139-67.

BRADLEY, R.S. (1973): Seasonal climatic fluctuations on Baffln Island during the period of instrumental records, Arctic Vol. 26, p. 230-243.

BRINKMAN, W.A.R. and BARRY, R.G. (1972): Paleoclimatological aspects of the synoptic climatology of Keewatin, Northwest Territories, Canada, Paleogeogr., Palaeoclimatol., Palaeoecol., Vol. 11, p. 77-91.

BRYSON, R.A. (1966): Air masses, streamlines and the boreal forest, Geogr. Bull., Vol. 8, p. 228-269.

BUDD, W.F. and SMITH, I.N. (1981): The growth and retreat of ice sheets in response to orbital radiation changes, in : I. Allison (ed. Symposium on Sea Level, Ice and Climate Change, Int. Assoc. Sci. Hydrol., Publ. 131 (in press).

CRANE, R.G. (1978): Seasonal variations of sea ice extent in the Davis Strait-Labrador Sea area and relationships with synoptic-scale atmospheric circulation, Arctic, Vol. 31, p. 434-447.

DAVIS, P.T. (1980): Holocene vegetation and climate record from Iglutalik Lake, Cumberland Sound, Baffin Island, N.W.T., Canada, in: Abstracts and Program, Amer. Quat. Assoc., Sixth Biennial Meeting, Univ. of Maine, Orono, p. 61. 
DENTON, G.H. and HUGHES, T.J. (Eds) (1981): The Last Great Ice Sheets, J. Wiley and Sons, New York, 484 p.

DEY, B. (1980): Seasonal and annual variations in ice cover in Baffin Bay and Davis Strait, Can. Geogr., Vol. 24, p. 368384.

DIAZ, H. and QUAYLE, R. (1980): The climate of the United States since 1895: Spatial and temporal changes, Mon. Wea. Rev., Vol. 108, p. 249-266.

FILION, R.H. (1980): A marine viewpoint on Late Wisconsinan ice sheet growth and disintegration in eastern North America, in : Abstracts and Program, Amer. Quat. Assoc., Sixth Biennial Meeting, Univ. of Maine, Orono., p. 76-77.

HARE, F.K. (1968): The Arctic, Quart. J. Roy. Met Soc., Vol. 94 , p. $439-459$.

HAWKINS, F.F. (1980): Trend surface analysis of present and paleo-equilibrium line altitudes in the Merchants Bay area, Baffin Island, Northwest Territories, Canada, in : Abstracts and Program, Amer. Quat. Assoc., Sixth Biennial Meeting, Univ. of Maine, Orono, p. 91.

JOHNSON, R.G. (1980): Some ice sheet and ocean current feedback effects on northern hemisphere summer energy inputs and distribution during Pleistocene glaciation, in: Abstracts and Program, Amer. Quat. Assoc., Sixth Biennial Meeting, Univ. of Maine, Orono, p. 112.

JOHNSON, R.G. and MCCLURE, B.T. (1976): A model for northern hemisphere continental ice sheet variation, Quat. Res., Vol. 6, p. 325-54.

KEEN, R.A. (1977): The response of Baffin Bay ice conditions to changes in atmospheric circulation patterns, Proceedings, Fourth International POAC Conference, St. John's, Newfoundland, Vol. II, p. 963-971.

(1980): Temperature and circulation anomalies in the eastern Canadian Arctic, summer 1946-76, Inst. Arct. Alp. Res., Occ. Pap. No. 34, Univ. of Colorado, Boulder, 159 p.

KREBS, J.S. and BARRY, R.G. (1970): The Arctic front and the tundra-taiga boundary in Eurasia, Geogr. Rev., Vol. 60, p. 548-554.

KASHAHARA, A. and WASHINGTON, W. M. (1971): General circulation experiments with a six-layer NCAR model, including orography, cloudiness and surface temperature calculations, J. Atmos. Sci., Vol. 28, p. 657-701.

NICHOLS, H. (1977): Transport of boreal forest pollen into the Canadian Arctic tundra, Final Report, GB-33497, National Science Foundation, Washington, D.C.

NICHOLS, H., KELLY, P.M. and ANDREWS, J.T. (1978): Holocene palao-wind evidence from palynology in Baffin Island, Nature, Vol. 273, p. 140-142.
PERRY, A.H. (1974): The downward trend of air and sea surface temperatures over the North Atlantic, Weather, Vol. 29, p. 451-55.

POTTER, J.G. (1965): Snow Cover, Climatol. Studies No. 3, Met. Branch. Dept. of Transport, Toronto, $69 \mathrm{p}$.

ROGERS, J.C. (1979): The North Pacific oscillation and eigenvectors of northern hemisphere atmospheric circulation during winter, Inst. Arct. Alp. Res., Occ. Pap. No. 31, Univ. of Colorado, Boulder, $177 \mathrm{p}$.

ROGERS, J.C. and VAN LOON, H. (1979): The seesaw in winter temperatures between Greenland and northern Europe. Part II. Some oceanic and atmospheric effects in middle and high latitudes, Mon. Wea. Rev., Vol. 107, p. 509519.

RUDDIMAN, W.F. and McINTYRE, A. (1979): Warmth of the subpolar North Atlantic Ocean during northern hemisphere ice-sheet growth, Science, Vol. 204, p. 173-175.

SHILTS, W.W. (1980): Flow patterns in the central North American ice sheet, Nature, Vol. 286, p. 213-218.

SMAGORINSKY, J. (1953): The dynamic influence of large scale heat sources and sinks on the quasi-stationary mean motions of the atmosphere, Quat. J. Roy. Met. Soc., Vol. 79 , p. 342-366.

SUGDEN, D.E. (1977): Reconstruction of the morphology, dynamics, and thermal characteristics of the Laurentide ice sheet at its maximum, Arct. Alp. Res., Vol. 9, p. 21-47.

TELLER, J.T. and FENTON, M.M. (1980): Late Wisconsin glacial stratigraphy and history of southeastern Manitoba, Can. J. Earth Sci., Vol. 17, p. 19-35.

VAN LOON, H. and ROGERS, J.C. (1978): The seesaw in winter temperatures between Greenland and Northern Europe. Part I: General description, Mon. Wea. Rev. Vol. 106, p. 296-310.

VAN LOON, H. and WILLIAMS, J. (1976a): The connection between trends of mean temperature and circulation at the surface: Part I. Winter, Mon. Wea. Rev., Vol. 104, p. 365380.

(1976b): The connection between trends of mean temperature and circulation at the surface : Part II. Summer, Mon. Wea. Rev., Vol. 104, p. 1003-1011.

WILLIAMS, L.D. (1978): Ice sheet initiation and climatic influences of expanded snow cover in Arctic Canada, Quat. Res., Vol. 10, p. 141-49.

(1979): An energy-balance model of potential glacierization of northern Canada, Arct. Alp. Res., Vol. 11, p. 443456.

WILSON, C.V. (1971): The Climate of Quebec. Part One: Climatic Atlas, Can. Meteorol. Serv. Downsview, Ontario. 